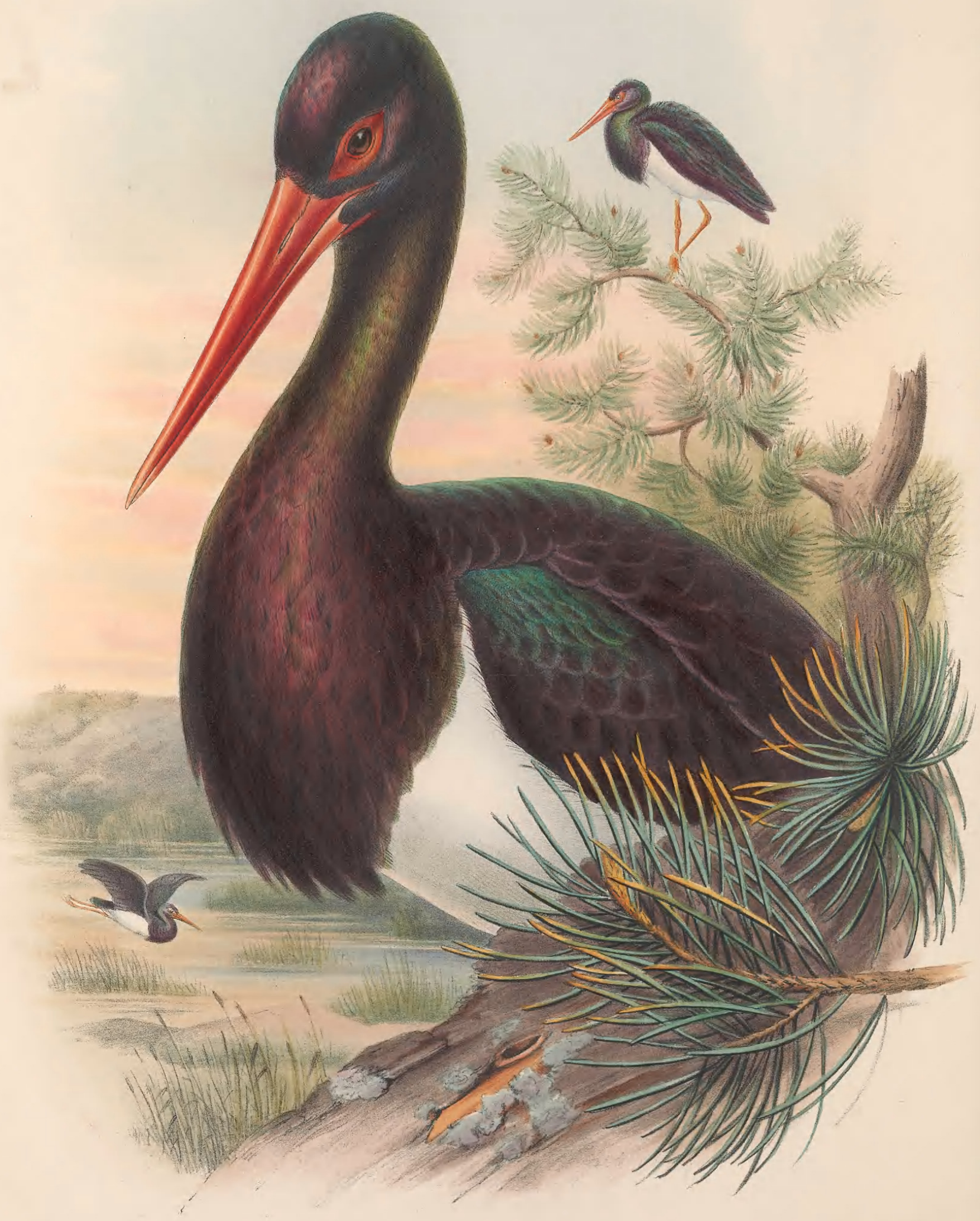




\section{CICONIA NIGRA.}

\section{Black Stork.}

Ardea nigra, Linn. Faun. Suec., p. 58.

Ciconia nigra, Bechst. Naturg. Deutschl., tom. iv. p. 96.

fusca, Briss. Orn., tom. v. p. 362, pl. 31.

Lrke the foregoing species, the Black Stork is a migratory bird. In the spring it advances to a much higher latitude than the White, visiting even Russia and Siberia, and passing over Sweden towards the north in considerable numbers; but it seldom comes so far westward as England. In Eastern Europe it is frequently met with; it is included by Schrenck among the birds of Amoorland; it also inhabits North Africa, and it is particularly abundant on the Nile, whence a fine specimen was brought to me by Mr. Cuthbert Larking. The Rev. H. B. Tristram states that it is found all through the winter in small flocks on the barren plains by the Dead Sea, never visiting the upper country, and mentions that he met with a flock of about two hundred, apparently searching for food, in the barren salt plain close to the border of that sea. They were too wary to allow him to approach within shot, but did not fly far when disturbed. As well as he could discover, they were feeding on the small snails which cluster on the twigs of the Salsola in that arid region.

In the islands of the Mediterranean it appears to be scarce; Mr. Wright notes it as rare at Malta and Gozo, and Lord Lilford as being equally so in the Ionian Islands; Messrs. Elwes and Buckley state that it is by no means numerous in Turkey, but that a pair is found here and there in Bulgaria.

Unlike the White, the Black Stork shuns rather than courts the society of man, " and," says Mr. Bennett, "makes its temporary divelling in the most secluded spots, frequenting impenetrable morasses or the banks of such rivers and lakes as are seldom disturbed by the presence of intruders, and building its nest on the summits of the loftiest pines." It would seem, however, that the situation of the nest depends much upon the nature of the locality; for Messrs. Elwes and Buckley state that in Bulgaria " the nest is usually built in a rock in a lonely situation, and is used for many consecutive years" : and Mr. W. H. Simpson, when speaking of the low cliffs which flank the lateral valleys and occasionally the stream of the Danube itself on the shore of the same country, states that they are favourite places for the larger birds of prey; but not of these alone, for the Black Stork also breeds there ; " at least," says he, "we discovered one nest in a very peculiar position for a bird which has the reputation of breeding in the densest thickets of impervious morasses. The cliff in this case was about sixty feet high, the strata being horizontal or nearly so. In the face of the upper ledge there had been at some time, artificially excavated in the soft stone, a chamber having a sort of antechamber, which communicated by means of a couple of steps with a crack in the rock, which it was not difficult to reach from the top when the exact path was once known. The chamber itself had much the appearance of a hermit's cell; but as the aperture in the face of the cliff was the entire width of one side, the apartment was airy and cheerful, commanding a fine view of the valley below. Altogether it was a place where one could have had no objection to put up for a few days in case of necessity. Here it was that a pair of Black Storks had taken up lodgings for the season, as we found out one morning about the 27 th of April. Some little time elapsed before we discovered the entrance from the top, a fact of which the Black Storks were probably not cognizant. At the time of our first visit there were no eggs, nor, indeed, was there any thing exactly worthy of the name of a nest. But in the floor of the chamber was a circular depression about the size and shape of a large dinner-plate, not far from the edge of the aperture. For what purpose this depression, evidently artificial, had been made, was to us as great a mystery as the origin of the entire excavation. The Black Stork had evidently thought she could put it to some use; for it was here, upon a few dry sticks which partially filled the depression, that she meant to lay her eggs. As it was necessary for me to leave Turkey about the 4 th of May, it was agreed not to approach the place again till the day before my departure. In the interim I used occasionally to take a stroll down the valley and seat myself on the opposite hill, where, throngh a telescope, I could see the Black Stork sitting composedly on her make-shift of a nest, looking like some spirit of darkness in its cave. Already I was counting the eggs, which would undoubtedly have been mine but for the evil curiosity of a Transylvanian shepherd, who had noticed me spying into the loole, and had perhaps seen us entering it. On the appointed day I rode over with a friend. Dismounting at the edge of the cliff we crept down to the crack in the rock, and thence through the artificial passage into the chamber itself. Neither bird nor eggs were visible; some great catastrophe had happened, and the eggs I had counted on, though laid, were missing. It transpired that the Transylvanian had done the deed, having 
probably sucked the eggs on the spot. We sought him everywhere, in the hope that he might have preserved them, but he was not to be found. Through the kindness of ny friend I was not wholly disappointed after all. The Black Stork laid two more eggs, which he secured and brought over to England the following summer. These are now in my collection. They are smaller than those of Ciconia alba, from which they may also be distinguished by a very faint greenish tinge being noticeable on closer inspection." More commonly the Black Stork resorts to the distant forests for the purpose of nesting and rearing its young, particularly those which are interspersed with streams and pools of water or marshy flats. "There towards the end of April," says Mr. Hewitson, "it builds its nest in solitude near the top of one of the lighest trees of the forest, for the most part upon that of the pine tree. The nest, though large, is less than that of the White Stork; its foundation of sticks is rendered more firm and stable by the addition of sods of earth, the remainder of the nest being completed with finer sticks. The eggs are four in number, very like but smaller than those of the White Stork."

The Black Stork is only an occasional or rare visitant to our islands, in proof of which I may mention that Yarrell enumerates only four specimens as having been killed in any part of them, namely-Colonel Montagu's bird on West Sedge Moor, in Somersetshire, in May 1814; one on the Tamar, in Devonshire, in November 1831, now in the possession of E. H. Rodd, Esq., of Penzance; another at Otley, near Ipswich in Suffolk, October 1832; and one on the south side of Poole Harbour, November 1839; to these, however, two more have been added by the Rev. F. O. Morris, namely, one killed on Market Weighton Common, in the East-Riding of Yorkshire, in October 1852, and a second, which Mr. Chaffey, of Dodington, informed him had been killed in the Weald of Kent. In addition to these Mr. A. Newton informed Mr. Stevenson "that Mr. Thornhill, of Riddlesworth, possesses a very fine specimen which he obtained in the flesh more than twenty years since of a labourer who had just shot it on some property of his own in Romney Marsh; and in Mr. J. H. Gurney's collection is a specimen said to have been killed at Poole in 1849 , just ten years later than the one before mentioned from the same locality." Besides the above, W. Christy Horsfall, Esq., states in the 'Zoologist' for 1862, under the date of September 8th, that he had just added to his collection a fine specimen which had been recently obtained at Hartlepool; and the Hon. Augusta Annesley has called my attention to another, which her friend F. D. Hibbert, Esq., stated had been shot on Otmoor about the middle of November 1862. To these another has yet to be added: on the 14th of June 1867, I received a letter from Mr. Antlıony Hammond informing me that a fine Black Stork had been shot on the banks of the river Nar, at Westacre, in the morning of the 19th of May. It had been about the meadows in the neighbourbood for a week and was always fishing. It proved to be an adult female, weighing over seven pounds, and is now in the fine collection of birds at Westacre High House.

The food of the Black Stork is precisely the same as that of its ally; in its search it wades deep in the water and kills its prey by shaking and beating before swallowing it. When about to fly, the bird takes one or two short leaps, and, when alighting, skims a short distance before touching the ground, and places its wingfeathers in order before it moves on further. It readily submits to captivity, and never uses its powerful bill offensively against its companions. The only sound made by the bird appears to be the clattering one produced by the repeated snapping of its mandibles.

Mr. Jerdon mentions, in his 'Birds of India,' that there " this bird is considered one of the finest quarries for the Bhyri (Falco peregrimus), and the day that a Black Stork is killed is marked by the Indian Falconer with a white stone."

There is no difference in the colouring of the sexes, and but little in size; the female is, however, a trifle smaller than the male.

The portion shown of the principal figure is nearly of the natural size. 


\section{$2 \mathrm{BHL}$ Biodiversity Heritage Library}

Gould, John. 1873. "Black Stork, Ciconia nigra [PI. 31]." The birds of Great Britain 4, -. https://doi.org/10.5962/p.323990.

View This Item Online: https://www.biodiversitylibrary.org/item/221609

DOI: https://doi.org/10.5962/p.323990

Permalink: https://www.biodiversitylibrary.org/partpdf/323990

\section{Holding Institution}

Smithsonian Libraries

\section{Sponsored by}

Biodiversity Heritage Library

\section{Copyright \& Reuse}

Copyright Status: Public domain. The BHL considers that this work is no longer under copyright protection.

This document was created from content at the Biodiversity Heritage Library, the world's largest open access digital library for biodiversity literature and archives. Visit BHL at https://www.biodiversitylibrary.org. 